\title{
Science Mapping of Sustainable Green Building Operation and Maintenance Management Research
}

\author{
Deddy Purnomo Retno ${ }^{1,2, *}$, M Agung Wibowo ${ }^{1}$, Jati Utomo Dwi Hatmoko ${ }^{1}$ \\ ${ }^{1}$ Department of Engineering, Diponegoro University, Indonesia \\ ${ }^{2}$ Faculty of Engineering, Universitas Islam Riau, Indonesia
}

Received November 17, 2020; Revised January 16, 2021; Accepted January 28, 2021

\section{Cite This Paper in the following Citation Styles}

(a): [1] Deddy Purnomo Retno, M Agung Wibowo, Jati Utomo Dwi Hatmoko , "Science Mapping of Sustainable Green Building Operation and Maintenance Management Research," Civil Engineering and Architecture, Vol. 9, No. 1, pp. 150-165, 2021. DOI: 10.13189/cea.2021.090113.

(b): Deddy Purnomo Retno, M Agung Wibowo, Jati Utomo Dwi Hatmoko (2021). Science Mapping of Sustainable Green Building Operation and Maintenance Management Research. Civil Engineering and Architecture, 9(1), 150-165. DOI: 10.13189/cea.2021.090113.

Copyright $\bigcirc 2021$ by authors, all rights reserved. Authors agree that this article remains permanently open access under the terms of the Creative Commons Attribution License 4.0 International License

\begin{abstract}
Green building is a solution to address the impact of buildings on the environment. In its development, green buildings require sustainable green management during the operational and maintenance phase in order to meet the current and future needs of users. As the longest phase in the green building life cycle, it is important to track and map the development of studies related to this field. This paper aims to map the development of literature related to the operational and maintenance phases of sustainable green buildings from 1999 to 2019. Literature data were obtained from the Scopus database and the analysis was conducted using a science mapping approach with VOSviewers. Based on literature data, 746 publications are found to be relevant to this study, the results of this study are in the form of scientific mapping covering wave of research, source and publication types, influential countries, references with strongest citation burst, author contributions, research subjects, and major research areas divided into three categories (frequent, medium and rare). The results of this study are quite important, because they not only provide a mapping of existing research developments, but can also serve as a reference for researchers who have an interest in developing sustainable green building operations and maintenance studies in the future.
\end{abstract}

Keywords Green Building, Operation and Maintenance, Science Mapping, VOSviewers

\section{Introduction}

Recently, many countries pay much attention to the increasing global warming, high energy consumption, and greenhouse gas emissions produced by buildings [1]. This condition requires immediate solutions in order to avoid serious risks that can impact on future generations [2], and one of the solutions is green building. Green buildings can be defined as how to produce structures by using environmentally responsible processes and using efficient resources during the life cycle of the building [3].

Green buildings are one way to reduce the significant impact of building on the environment, society, and economy. Along with the increasing attention to this issue, related scientific works also evolve over time. Given the importance of green buildings in reducing the environmental impact in the world, mapping the development of scientific works in this field is important.

Some systematic studies based on a bibliography of the development of green building research have been conducted. Among them are current research reviews of green buildings and agendas in the future [4], a review of the bibliometrics improvement of building maintenance within the period of 2000 to 2016 [5], a scientometric study of green buildings using Data envelopment Analysis (DEA) during the period of 1965 to 2019 [6], scientometric review of the recycling industry from 1996 to 2018 [7], scientometric review trend of green manufacturing publications in the period of 1996 to 2018 [8], and research challenges and barriers in obtaining GBCA ratings for office buildings in Australia using literary studies during the period of 2004 to 2011 [9].

However, from many studies which try to map the development of literature related to green buildings, a gap is found, namely the mapping of Scientific works that 
review the operational and maintenance phases of green buildings. Green buildings include all operations from planning, construction, operation, maintenance, repair and demolition of buildings [10]. So far, much research has focused on investigating obstacles of the design and construction of green buildings with very little focusing on the operation and maintenance phases [11]. This condition is quite interesting to do a mapping, considering that the operation and maintenance phase is the longest phase of a building life cycle and this study is also expected to complement other existing green building phase mapping studies. Some studies show that this phase plays an important role in maintaining the current user value system without compromising the ability to meet the value system for users in the future [12].

This paper is aimed at filling the existing gaps of research on green buildings, especially publications discussing the operational phase and maintenance of sustainable green buildings from 1999 to 2019. The activity of mapping scientific boundaries requires more than merely presenting an intuitively designed and presented science [13], and to bridge the matter in this study using a science mapping approach.

Scientific mapping is very useful to know the development of literature in relation to the development of science that is reviewed, because scientific mapping aims to build a bibliometric map describing how certain disciplines, scientific domains, or research areas are conceptually arranged, intellectually, and socially [14].

In this paper, the scientific mapping activity was done by using VOSviewers software and the Bibliometric data were obtained from the metadata owned by Scopus. The research on studies will feature analyses and discussions that include the development of literary publications covering the number of publications, sources and types of publications, number of citations, author contributions, research subjects, and major research areas of the topic being reviewed.

\section{Research Methods}

This paper encapsulates Published research on Sustainable Green Building Operation and Maintenance Management obtained from Scopus metadata within the period of 1999 to 2019. This study employed science mapping approach with VOSviewers software. This paper does not provide a detailed analysis of all available studies. It quantitatively summarized the conditions of existing literature and trends in the development of literature on the management of operation and maintenance of sustainable green buildings so that readers can systematically understand the development of existing publications, sources and types of publications, contributions of countries of origin of publication, developments in the number of citations, contributions of authors, subject areas research and key research areas.

The stages of this study started from identifying the research gap of existing green building literature-based studies. From this activity, a gap in the literature discussing the operation and maintenance of sustainable green buildings was found. Based on the gap, the purpose of the study to be done was then formulated. The primary objective of the study is to conduct science mapping on sustainable green building operation and maintenance management research. The next stage was the withdrawal of literature metadata based on the selected bibliography database (obtained from Scopus). Then, the next step was an analysis using VOSviewers software followed by discussions of the findings. At last, conclusions were drawn.

\subsection{Database Selection}

This paper uses a bibliography data in CSV format, which were withdrawn from Scopus database. For directing the study, this paper uses keywords from titles, abstracts and keyword of database literature consisting of "sustainable green building operation and maintenance management", "Sustainable Green building operation Management", "Sustainable green building Maintenance management", "Sustainable Green building operation" and "sustainable green building maintenance". This paper also limits the subject of research which covers only the fields of Engineering, Environmental Science, Energy, Social Sciences, Business, Management and Accounting, Computer Science, Materials Science, Earth and Planetary Sciences, and Decision Sciences.

\subsection{Science Mapping}

Science is a gateway to understanding the position of humans in the universe, and a foundation for social and economic welfare [13]. Using the science mapping method, the development of science can be mapped properly and this map can change and develop along with the development of science itself. The science mapping approach displays the structural and dynamic aspects of scientific research; it is a spatial representation of how disciplines, fields, and writers relate to one another [15]. A mature visual analytical field can provide promising pursuit directions. Visual analytics can be seen as the second generation of information visualization [13].

Basically, the process of science mapping consists of 3 conceptual steps to produce a natural map [13]. These steps are: selection of analytical units consisting of basic particles of the universe of science reviewed, defining the size of the relationship between units, and describing units and relationships reviewed in low-dimensional space (generally using two dimensions).

Nowadays, many computer applications can be used for science mapping, such as CiteSpace (2003), Science of Science Tool (2009), VOSviewers (2010), and SciMAT (2012) [13]. In this study, the mapping process used VOSviewers software. VOSviewers is one of the computer applications that is considered capable and is widely used in processing metadata sourced from Scopus. VOSviewer is used to establish a network of scientific 
publications, scientific journals, researchers, research organizations, countries, keywords, or terms [16]. VOSviewers can create maps based on network data and visualize the maps in the form of network visualization, overlay visualization, and density visualization [16].

\section{Results and Discussion}

\subsection{Wave of Research on Sustainable Green Building Operation and Maintenance}

Figure 1 indicates the development of publications starting from the beginning of publication that correlates with sustainable green building operation and maintenance within the period of 1999 to 2019. Based on data from Scopus, 746 documents were identified, with 116 open-access documents and 630 non-open access documents.

Publications related to sustainable green building operations and maintenance first appeared in 1999, comprising research on the selection of cost effective using the BEES method [17], a comparison between embodied energy and energy use in the operational phase of the wooden row house [18], the development of scenarios of green building challenges (GBC) using the life cycle assessment method in the operational phase and refurbishment of existing buildings [19], and the assessment of green building challenges in the UK [20].

Between 1999 and 2004, the number of publications was still very small (less than 10 documents). In this period, many researchers tended to focus primarily on the initial challenges faced by green buildings which began to develop and spread around the world. Therefore, the scope of the study mostly revolves around the design and construction of green buildings. However, over time the publications that discussed the operation and maintenance phases grew gradually. This can be seen from the number of publications that grew rapidly, especially in 2005 to 2013. Although after that, the number of publications seemed stagnant, but the quantity was quite large. This shows the longest phase in the green building life cycle. The operation and maintenance phase is starting to get the attention of researchers to conduct studies specifically to maintain the condition of existing green buildings.

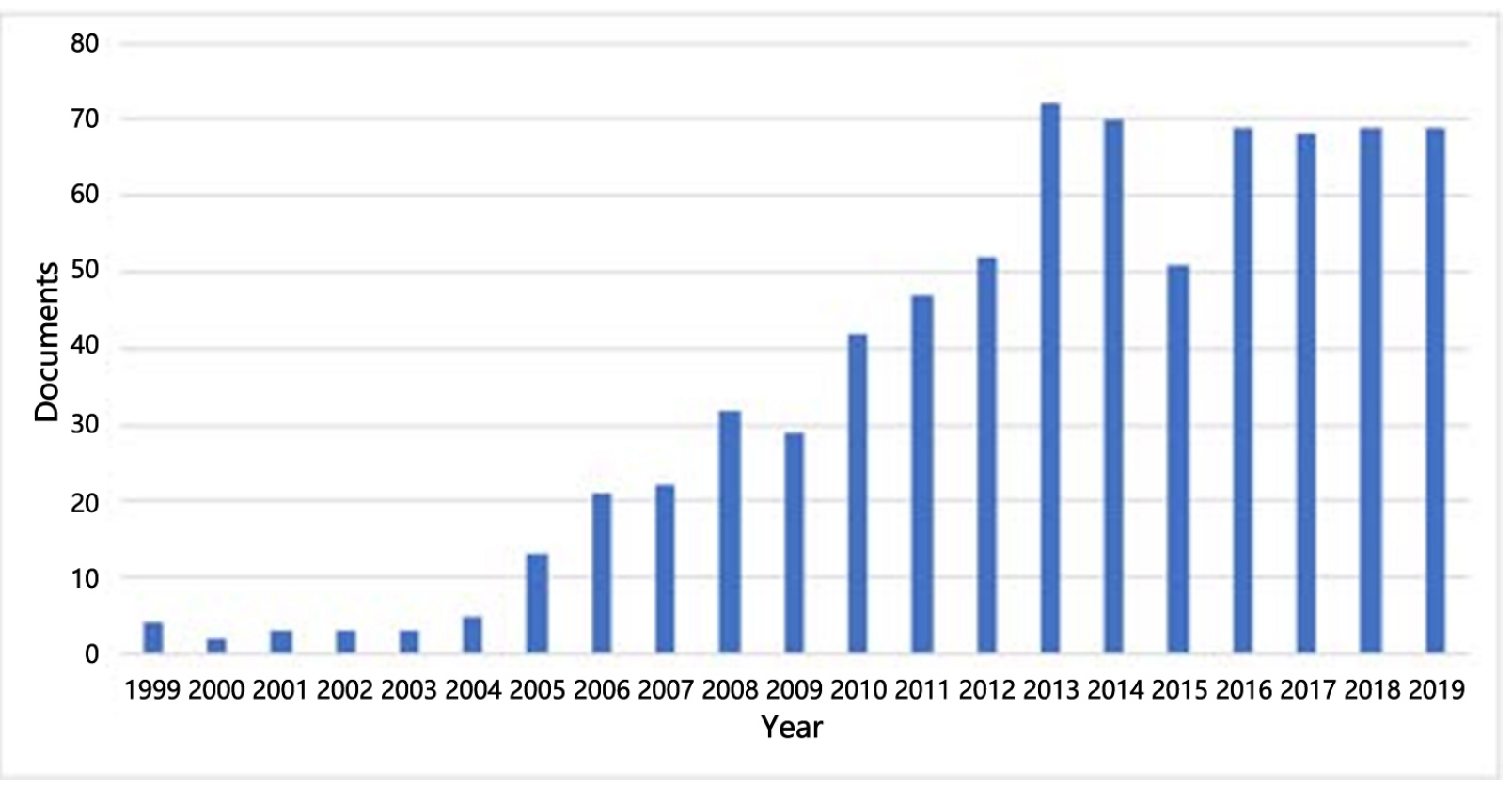

Figure 1. Publication Developments $(1999$ - 2019) 


\subsection{Top Research Outlets}

Based on Scopus metadata from 1999 to 2019, of the 746 publications found, article publications and conference proceedings contributed the most (86.2\%) compared to other sources and contributes greatly to the development of studies in this field. Based on Table $\mathbf{1}$ it can be noted that article (322 publications) accounted for $43.2 \%$, conference paper (321 publications) $43.0 \%$, and conference review (32 publications) 4.3\%. This condition shows that publication through journal articles and conference papers is the main channel for researchers to convey the results of their studies, thoughts and opinions on this topic.

Table 1. Publication type

\begin{tabular}{|c|c|c|}
\hline Document type & Documents & \% \\
\hline Article & 322 & $43.2 \%$ \\
\hline Conference Paper & 321 & $43.0 \%$ \\
\hline Conference Review & 32 & $4.3 \%$ \\
\hline Review & 30 & $4.0 \%$ \\
\hline Book Chapter & 26 & $3.5 \%$ \\
\hline Book & 9 & $1.2 \%$ \\
\hline Short Survey & 5 & $0.7 \%$ \\
\hline Undefined & 1 & $0.1 \%$ \\
\hline
\end{tabular}

According to the metadata of Scopus, it is known that there are 88 sources of publications during the period of 1999 to 2019. Based on Figure 2, the top 10 sources of the highest contribution consisting of: Journal of Green Building (25 documents), Advance Material Research (24 documents), Applied Mechanics And Materials (21 documents), Journal of Cleaner Production (20 documents), and the Earth and Environmental Science IOP Conference Series (17 documents), Procedia Engineering (17 documents), Building Research and Information (11 documents), Sustainability Switzerland (11 documents), Energy and Buildings (10 documents), and Energy Procedia (10 documents).

The Advance Material Research Journal is a journal that first published the results of research in early 1999, 2001, 2002, 2007, 2008, 2011, 2012, 2013 and 2014. The Journal of Green Building first published research in this field in 2006 to 2018, where papers on this topic could always be found in each publication. Energy and Building published articles in 2007, 2010, 2011, 2013, 2014, 2015, and 2017. Journal of Cleaner Production published articles in 2011, 2013, 2014, 2015, 2017, and 2019. Energy Procedia published articles in 2011, 2014, 2016, 2017, and 2019. The journal of Procedia Engineering published literature related to topics in the years of 2011, 2014, 2015, 2016, and 2017. Applied Mechanics and Materials publications were found in 2012, 2013 and 2014. For IOP Conference Series Earth and Environmental Science, articles are found in the year of 2013, 2014, 2015, 2017, 2018, and 2019. In Building Research and Information, relevant articles are found in the years of 2015 and 2018. Sustainability Switzerland published articles from 2014 to 2019.

Based on the previous explanation, in this study, the Journal of Green Building is the main choice outlet for researchers to publish their articles, while the IOP Conference Series Earth and Environmental Science is the largest outlet that publishes conference papers that have a correlation with the operation and maintenance phases of green buildings.

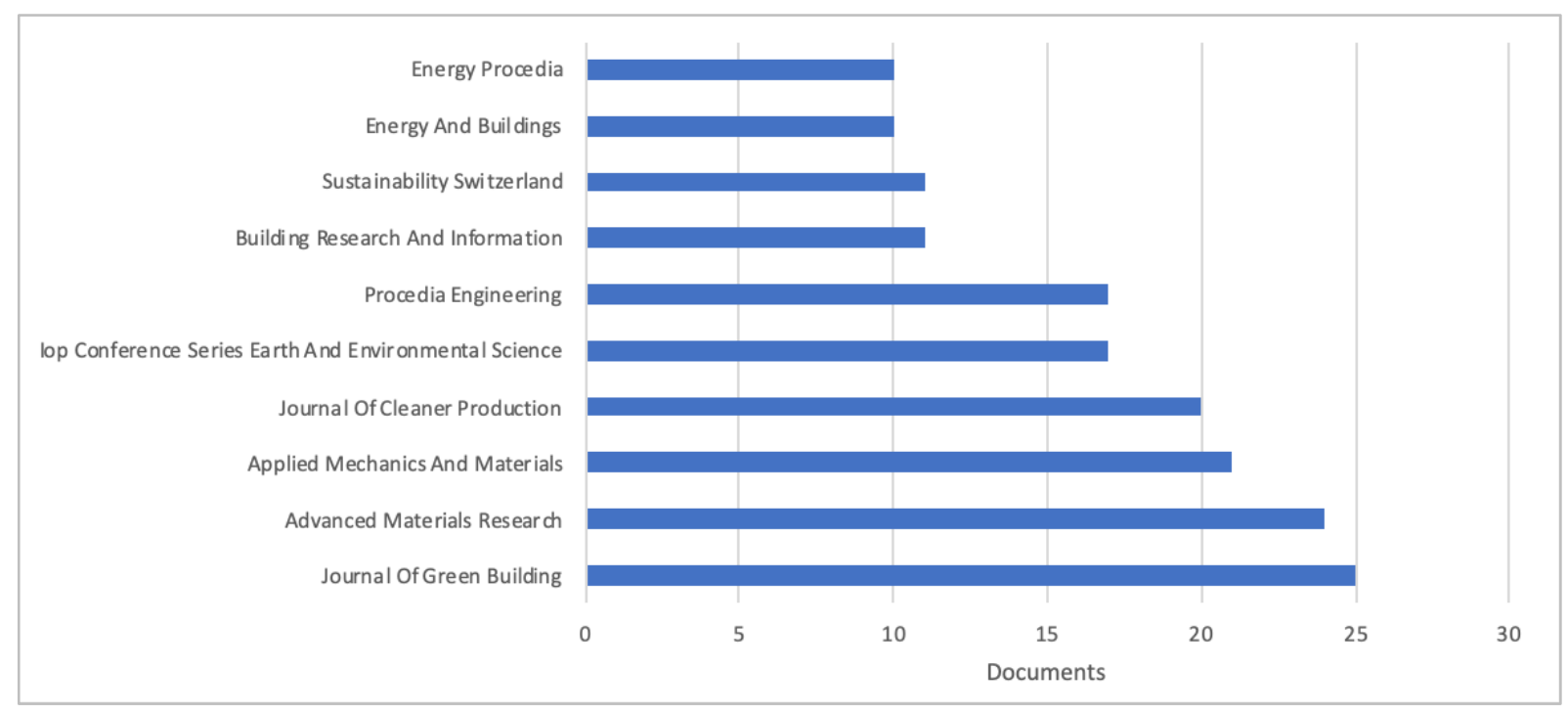

Figure 2. Top 10 Research Outlets 


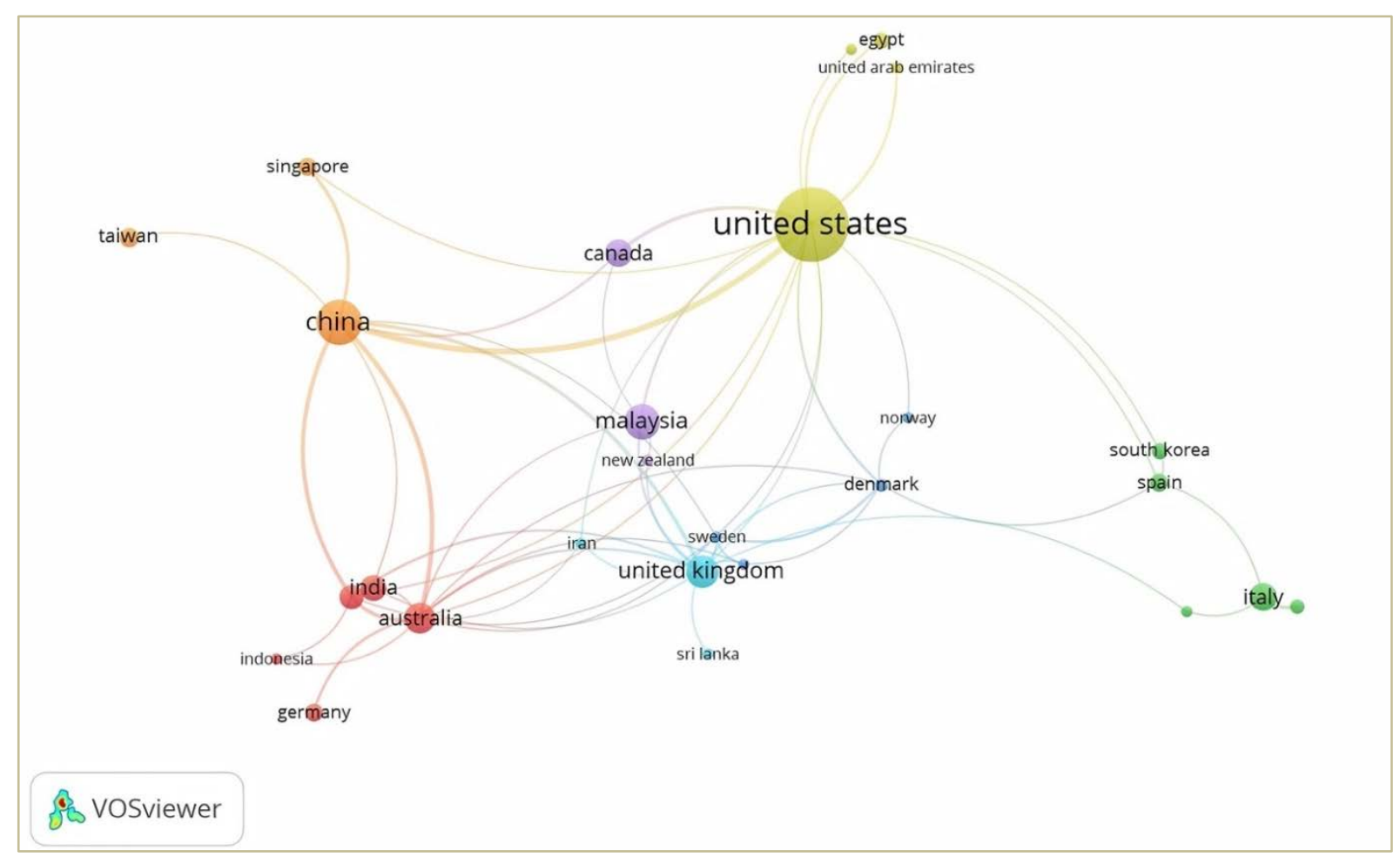

Figure 3. Network Visualization

\subsection{Influential Countries}

Academic paper publications can usually be considered as indicators of a scientific discipline development [7] and changes in the number of publications can indicate the development or change of a science [13].

Based on the Scopus dataset, 82 countries have contributed during the period of 1999 - 2019. Productivity mapping based on the contribution of these countries used co-authorship analysis and full counting calculation methods with a minimum number of publications $=5$. The results obtained are 28 countries with 7 clusters from 82 countries that meet these requirements. Cluster 1 consists of Australia, Germany, Hong Kong, India, and Indonesia. Cluster 2 consists of Italy, the Netherlands, Russia, South Korea, and Spain. Cluster 3 consists of Brazil, Denmark, Norway, and Sweden. Cluster 4 consists of Egypt, Turkey, the United Arab Emirates, and the United States. Cluster 5 consists of Canada, Malaysia, and New Zealand. Cluster 6 consists of Iran, Sri Lanka, and the United Kingdom. Cluster 7 consists of China, Singapore, and Taiwan. The results are visualized in Figure 3 . The size of the contribution of a country is represented by the size of the node.

Measuring the number of citations, based on Figure 3, for the 5 countries with the largest contributions, the 3 publications with the most citations in each country are as follows: in the United States, research on The moderating effects of institutional pressures on emergent green supply chain practices and performance [21] have 509 citations, then Balancing priorities: Decision-making in sustainable supply chain management [22] with 361 citations, and research on Sustainable energy performances of green buildings: A review of current theories, implementations and challenges [22] with 155 citations. In China, 3 publications with the highest number of citations consisted of The moderating effects of institutional pressures on emergent green supply chain practices and performance [21] with 509 citations, Green strategy for gaining competitive advantage in housing development: A China study [23] with 163 citations, Urbanization and its impact on building energy consumption and efficiency in China [24] with 130 citations. Malaysia with the publication of Sustainable energy performances of green buildings: A review of current theories, implementations and challenges [25] with 155 citations, A vision on the role of environmental higher education contributing to sustainable development in Malaysia [26] with 46 citations, and Green maintenance for historic masonry buildings: an emerging concept [27] with 27 citations. In the UK the publication of Urbanization and its impact on building energy consumption and efficiency in China [24] with 130 citations, Green operations initiatives in the automotive industry: An environmental reports analysis and benchmarking study [28] with 110 citations, Sustainability: A new imperative in contaminated land remediation [28] with 105 citations. From Australia, the publications of the Sustainable construction-The role of environmental assessment tools [29] with 571 citations, Barriers to implement extensive green roof systems: A Hong Kong Study [30] 94 citations, Eco-resorts vs. Mainstream accommodation providers: An investigation of The viability of benchmarking environmental performance [31] with 52 citations.

Table 2 shows the order of 28 countries based on the number of publication contributions including information on the number of citations and the total link strength 
possessed. The 10 countries with the largest contributions are as follows: United States (221 publications), then China (84 publications), Malaysia (52 publications), United Kingdom (42 publications), Australia (38 publications), Italy (38 publications), Canada (31 publications), India (27 publications), Hong Kong (26 publications), and Taiwan (16 publications). These data show that the United States dominates the publication and makes a major contribution to the study of the stages of operation and maintenance of green buildings. This is indicated by the large number of publications, the number of citations and the total link strength generated.

Table 2. Country Rankings by Number of Publications

\begin{tabular}{|c|c|c|c|c|c|c|c|c|c|}
\hline No & Country & Documents & Citations & $\begin{array}{c}\text { Total link } \\
\text { strength }\end{array}$ & No & Country & Documents & Citations & $\begin{array}{c}\text { Total link } \\
\text { strength }\end{array}$ \\
\hline 1 & united states & 217 & 2575 & 32 & 16 & netherlands & 9 & 184 & 3 \\
2 & china & 84 & 1361 & 33 & 17 & denmark & 8 & 63 & 9 \\
3 & malaysia & 52 & 386 & 7 & 18 & brazil & 6 & 200 & 4 \\
4 & united kingdom & 42 & 558 & 19 & 19 & indonesia & 6 & 20 & 2 \\
5 & australia & 38 & 963 & 22 & 20 & iran & 6 & 34 & 3 \\
6 & italy & 32 & 469 & 5 & 21 & new zealand & 6 & 68 & 2 \\
7 & canada & 31 & 826 & 7 & 22 & russian & 6 & 6 & 2 \\
8 & india & 27 & 106 & 4 & 23 & sweden & 6 & 109 & 8 \\
9 & hong kong & 26 & 640 & 15 & 24 & turkey & 6 & 31 & 1 \\
10 & taiwan & 16 & 61 & 1 & 25 & united arab & 6 & 26 & 2 \\
11 & germany & 14 & 271 & 2 & 26 & norway & 5 & 90 & 2 \\
12 & singapore & 14 & 183 & 4 & 27 & poland & 5 & 28 & 0 \\
13 & spain & 13 & 75 & 4 & 28 & sri lanka & 5 & 14 & 1 \\
14 & egypt & 11 & 50 & 2 & & & & & \\
15 & south korea & 11 & 22 & 2 & & & & & \\
\hline
\end{tabular}

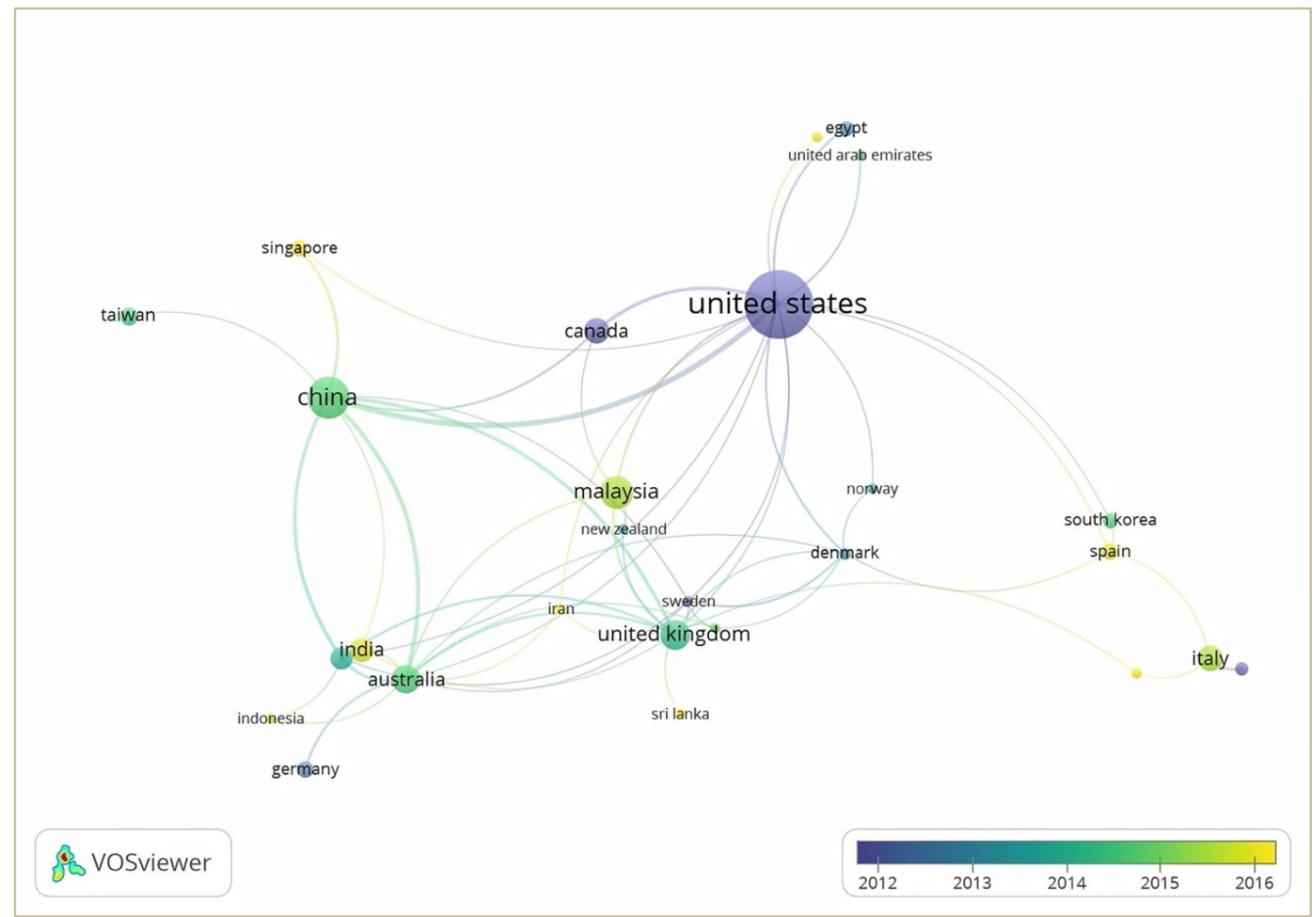

Figure 4. Overlay Visualization 
The overlay visualization (Figure 4) presents the periodization of publications based on country contributions. The results of the overlay visualization show that the United States is the pioneer of publications dealing with research topics in this field. Publications that correlate with research topics were first discovered in the United States in 1999 on the selection of cost effective green buildings [32] with 79 citations and 3 other publications, such as research on the challenges of green buildings from the perspective of observers [19] with 113 citations, Green building challenges in England [20] with 28, and solar and green calculations on the Norwegian Row House [18] with 76 citations.

\subsection{Author Contributions}

Analysis of the authors ' contributions was done using the co-authorship analysis with the authors as a unit of analysis with full counting calculation method. The threshold used is the minimum number of documents of an author numbering 3 documents and a minimum number of citations of an author amounting to 3 citations.
Based on the Authorship mapping (Figure 5), 19 clusters consisting of 30 authors were obtained. Each cluster is marked with its own color. 10 authors with the largest contribution are Perini, K. (6 documents), Wang, Y. (6 documents), Chew, M.Y.L. (5 documents), Zhang, X. (4 documents) and Li, B. (4 documents), Roper, K.O. (4 documents), Che-ani, A.I (4 documents), Conejos, S. (4 documents), Shen, L. (3 documents) and $\mathrm{Wu}, \mathrm{Y}$. (3 documents). The 10 authors with the highest number of citations are Zhang, X. (300 citation), Shen, L. (284 citation), Wu, Y. (191 citation), Perini, K. (187 citation), Li, B. (171 citation), Ottelé, M. (166 citations), Lu, Y. (102 citations), Wang, Y. (92 citations), Lippiatt, B.C. (80 citations), and Hormones, M. (76 citations).

Figure 6 shows the results of the overlay visualization mapping authors. In the picture, the darker the color of the node indicates the older a literature and when it goes to bright yellow, the literature will get younger. The literature begins by Lippiatt, B.C, and Cole, L.J. Then, it proceeds with Horman, M., and Ropper, K.O. and publications related to this field continue to grow to this day.

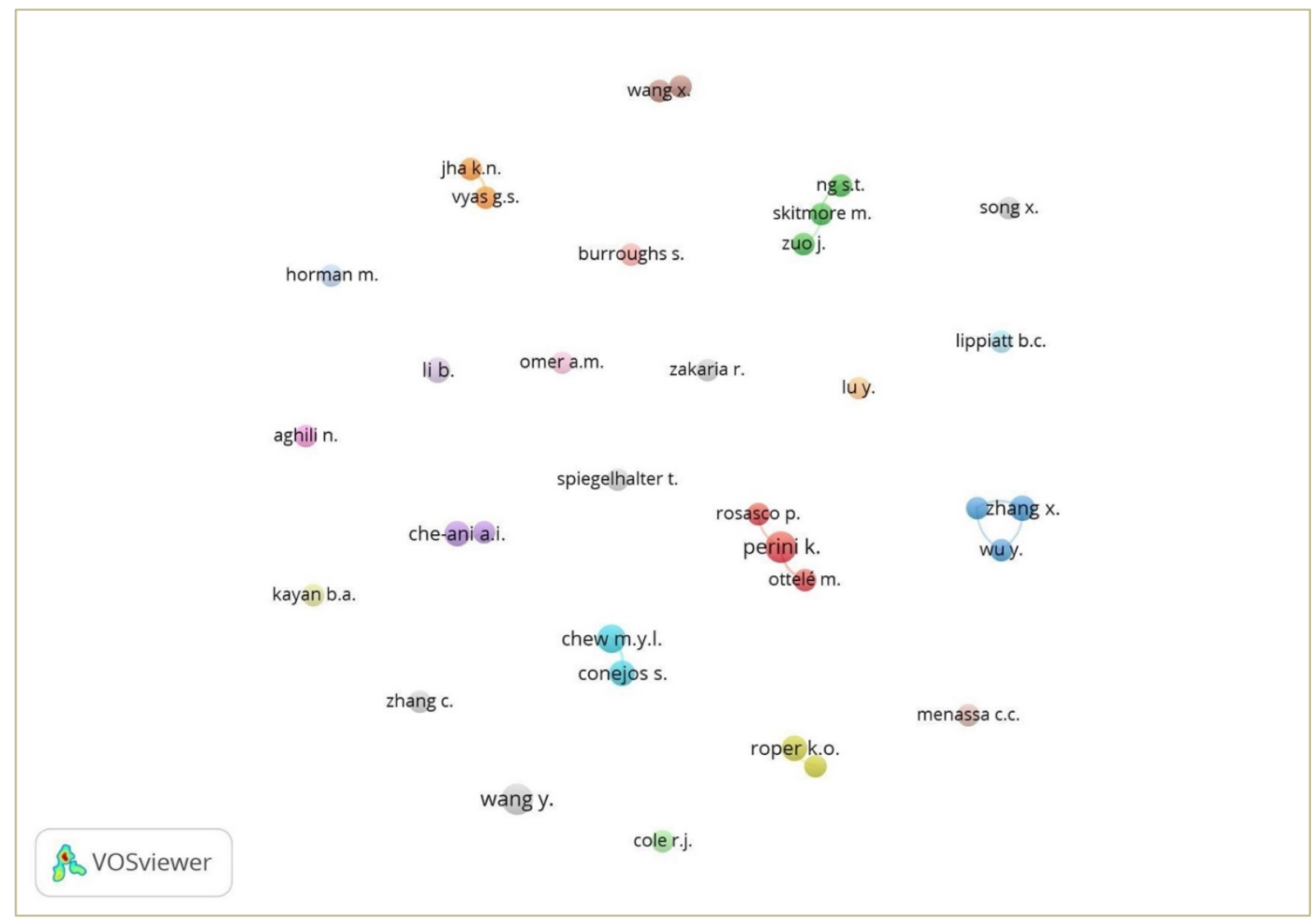

Figure 5. Authorship Network Visualization 


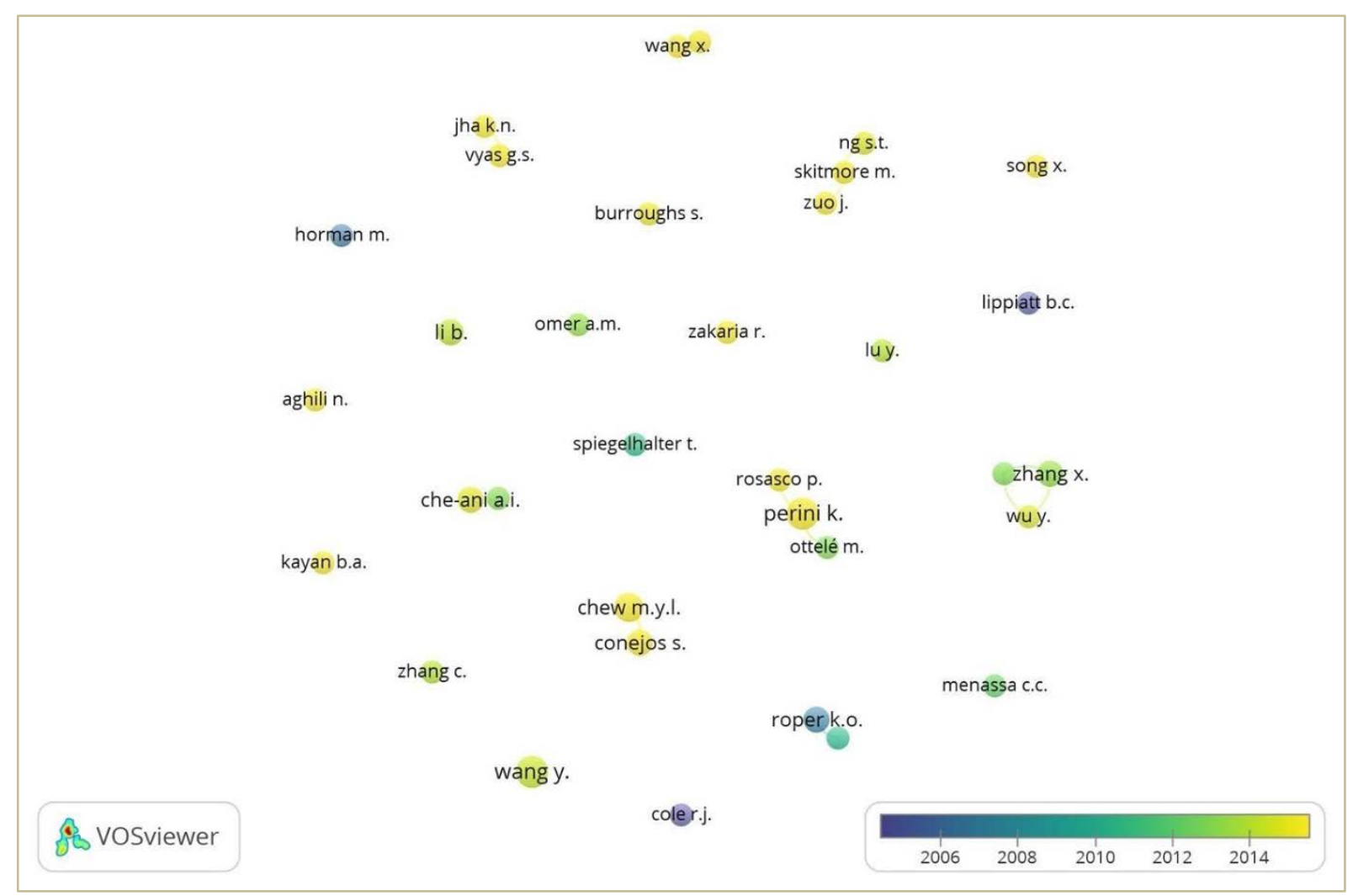

Figure 6. Overlay Visualization

Table 3. Top 20 References with Strongest Citation Burst

\begin{tabular}{|c|c|c|c|}
\hline Documents & $\begin{array}{c}\text { Publication } \\
\text { Year }\end{array}$ & Country & $\begin{array}{c}\text { Total } \\
\text { Citation }\end{array}$ \\
\hline Sustainable construction-The role of environmental assessment tools [29] & 2008 & Australia & 562 \\
\hline $\begin{array}{l}\text { The moderating effects of institutional pressures on emergent green supply chain practices } \\
\text { and performance [21] }\end{array}$ & 2007 & China & 498 \\
\hline Balancing priorities: Decision-making in sustainable supply chain management [22] & 2011 & US & 355 \\
\hline $\begin{array}{l}\text { Green strategy for gaining competitive advantage in housing development: A China Study } \\
\text { [23] }\end{array}$ & 2011 & Hongkong & 161 \\
\hline $\begin{array}{l}\text { Energy analysis of building manufacturing, maintenance and use: Em-building indices to } \\
\text { evaluate housing sustainability [33] }\end{array}$ & 2007 & Italy & 155 \\
\hline $\begin{array}{c}\text { Sustainable energy performances of green buildings: A review of current theories, } \\
\text { implementations and challenges [25] }\end{array}$ & 2013 & Malaysia & 151 \\
\hline $\begin{array}{l}\text { Enhancing environmental sustainability over building life cycles through green BIM: A } \\
\text { review [39] }\end{array}$ & 2015 & Hongkong & 132 \\
\hline Urbanization and its impact on building energy consumption and efficiency in China [24] & 2009 & China & 129 \\
\hline Comparative life cycle analysis for green façades and living wall systems [37] & 2011 & Netherland & 115 \\
\hline $\begin{array}{c}\text { Green Human Resource Management and Green Supply Chain Management: Linking two } \\
\text { emerging agendas [35] }\end{array}$ & 2016 & Brazil & 115 \\
\hline The relevance of Green Building Challenge: An observer's perspective [19] & 1999 & Germany & 113 \\
\hline $\begin{array}{l}\text { Green operations initiatives in the automotive industry: An environmental reports analysis } \\
\text { and benchmarking study [28] }\end{array}$ & 2010 & UK & 110 \\
\hline $\begin{array}{c}\text { Decision making, planning and design for the conservation of indigenous vegetation } \\
\text { within urban development [38] }\end{array}$ & 2004 & Austria & 107 \\
\hline Building sustainability in logistics operations: A research agenda [36] & 2011 & US & 103 \\
\hline Sustainability: A new imperative in contaminated land remediation [40] & 2014 & UK & 95 \\
\hline Sizing of rainwater storage units or green building applications [41] & 2007 & Canada & 94 \\
\hline Barriers to implement extensive green roof systems: A Hong Kong study [30] & 2012 & Hongkong & 94 \\
\hline $\begin{array}{l}\text { Economic returns to energy-efficient investments in the housing market: Evidence from } \\
\text { Singapore [34] }\end{array}$ & 2012 & Singapore & 90 \\
\hline The next generation of sustainable construction [42] & 2007 & US & 83 \\
\hline Selecting cost-effective green building products: BEES approach [17] & 1999 & US & 79 \\
\hline
\end{tabular}




\subsection{References with Strongest Citation Burst}

The number of citations for publications that have relevance to research topics continues to grow from year to year. Based on the dataset used from the years of observation 1999 - 2019, 20 documents were obtained with the highest number of citations as shown in Table 3. The countries of origin for the 20 publications with the most citations were the United States with 4 documents, Hong Kong with 3 documents, China with 2 documents, England with 2 documents, while Australia, Italy, Malaysia, Netherlands, Brazil, Germany, Austria, Canada and Singapore each with 1 document.

Table 3 shows that research on environmental assessment of sustainable construction [29] has the highest number of citations with 562 citations. Based on 20 papers with top citation, it is known that the research area with the most citations is in the realm of energy [24] [25] [33] [34], Supply Chain [21] [22] [35] [36], and the use of vegetation in green buildings [30] [37] [38].

Based on the number of citations, it is known that the discussion of environmental assessment is still an interesting study and many other researchers have cited it, as well as the discussion of supply chains. This can be seen from the large number of citations held by titles that discuss this matter, such as: Sustainable construction-The role of environmental assessment tools [29] with 562 citations, The moderating effects of institutional pressures on emergent green supply chain practices and performance [21] with 489 citations, and Balancing priorities: Decision-making in sustainable supply chain management [22] with 355 citations.

\subsection{Main Subject Area of Research}

This paper reviews the 9 subjects of the research area consisting of engineering, environmental science, energy, social science, business, management and accounting, computer science material science, Earth and Planetary science, and the decision sciences. The number of publications and the percentage of contributions based on the subject area can be seen in Table 4 .

Table 4. Subjects of Research Areas

\begin{tabular}{|c|c|}
\hline Subject Area & \% \\
\hline Engineering & 37.8 \\
\hline Environmental Science & 17.6 \\
\hline Energy & 11.6 \\
\hline Social Sciences & 11.1 \\
\hline Business, Management and Accounting & 7.2 \\
\hline Computer Science & 5.3 \\
\hline Materials Science & 4.3 \\
\hline Earth and Planetary Sciences & 3.1 \\
\hline Decision Sciences & 2.1 \\
\hline
\end{tabular}

Within the period of 1999 - 2019, the subject areas that dominated the publications discussing the operation and maintenance phases of sustainable green buildings were engineering subject with 451 documents, environmental science with 210 documents, energy with 139 documents, social science with 132 documents, and business, management, and accounting with 86 documents.

Figure 7 shows the proportion of the size of subject areas contribution to the number of publications which are relevant to sustainable green building operations and maintenance. Engineering contributed 37.8\%, followed by Environmental Science, 17.6\%, Energy 11.6\%, Social Sciences $11.1 \%$, Business, Management, and Accounting 7.2\%, Computer Science, 5.3\%, Materials Science, 4.3\%, Earth and Planetary Sciences 3.1\%, and Decision Sciences $2.1 \%$.

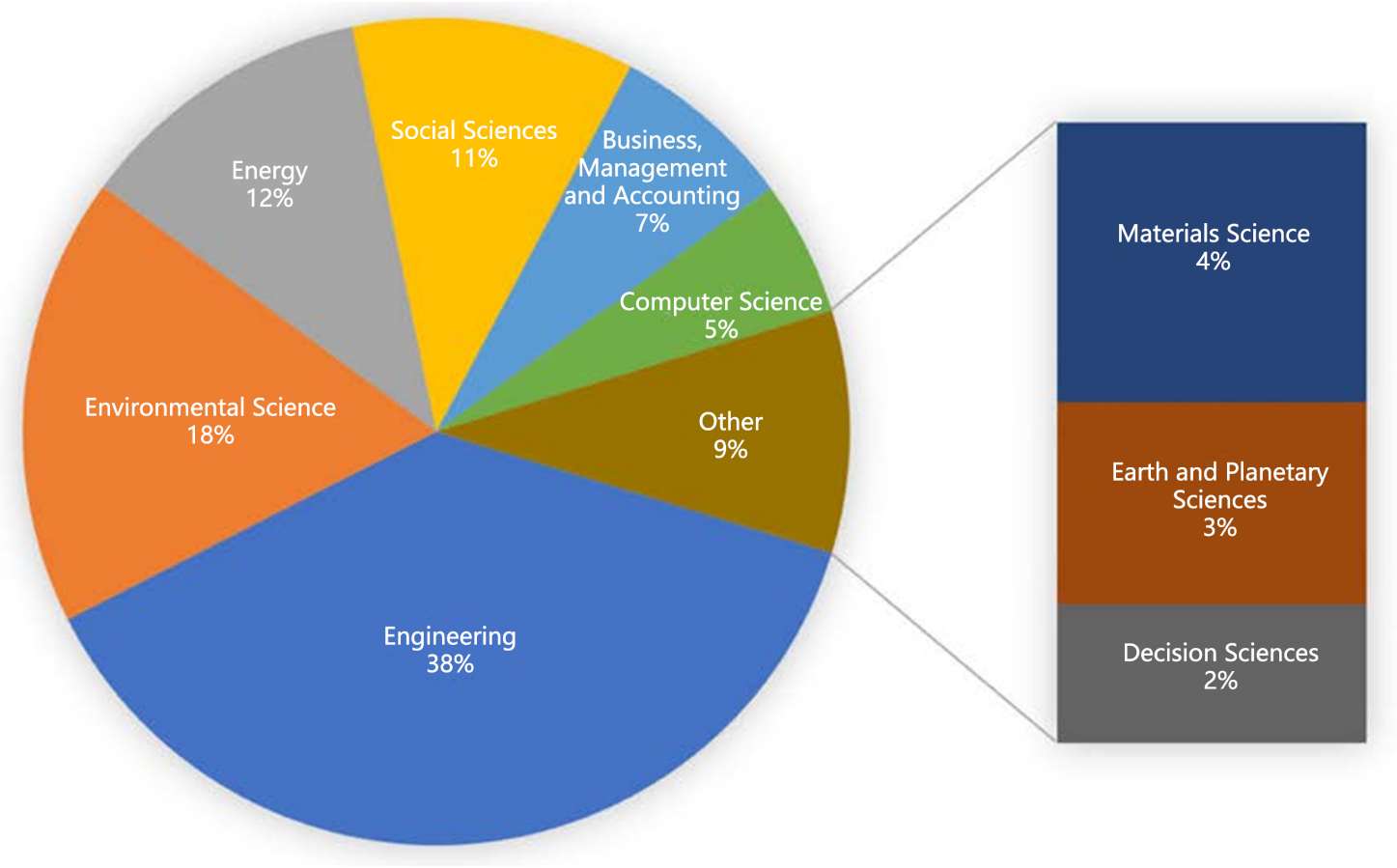

Figure 7. Distribution of Publications by Subject Area 
This condition shows that the main subject areas of study so far are still in the areas of engineering, environmental science and energy, with very few links to other subject areas, such as: social science, computer science and materials science and others. Considering the operation and maintenance phase is a phase that consists of a compilation of many disciplines, it very possible to open up other opportunities for studies using various perspectives of scenarios and other scientific field approaches.

\subsection{Major Research Areas (Analysis of Keywords Co-Occurrences)}

Mapping all keywords can provide an overview of the main research areas that have been investigated [43]. This study found 5285 keywords that have a relationship with the phase of operation and maintenance of sustainable green buildings. However, in order to dissolve the study, the number of keywords will be limited using the following parameters: analysis based on co-occurrence, calculation using full counting and all keywords as an analysis unit [44][45][46], and using the threshold occurrence of a keyword of 20. Based on the parameters, 53 keywords that can fulfill these requirements are obtained and these keywords can be grouped into 5 clusters as shown in Figure 8.

As Figure 8 shows, cluster 1 is a collection of 13 items consisting of buildings, cost-benefit analysis, costs, decision making, environmental impact, environmental sustainability, housing, life cycle, life cycle assessment, LCA, maintenance, operation and maintenance, and sustainability. Cluster 2 is a collection of 12 items consisting of water quality, buildings, carbon dioxide, energy conservation, energy efficiency, energy use, energy utilization, global warming, historic preservation, investment, office building, and Solar energy. Cluster 3 is a collection of 12 items consisting of building codes, building materials, design, ecology, environmental protection, green buildings, planning, societies and institution, strategic planning, structural design, sustainable design, and sustainable development. Cluster 4 is a collection of 10 items consisting of building construction, carbon, climate change, construction, industrial construction, environmental management, green building, greenhouse gases, project management, and sustainable construction. Meanwhile, cluster 5 is a collection of 6 items consisting of architectural design, environmental design, intelligence building, leadership in energy and environmental design, LEED, and sustainable building.

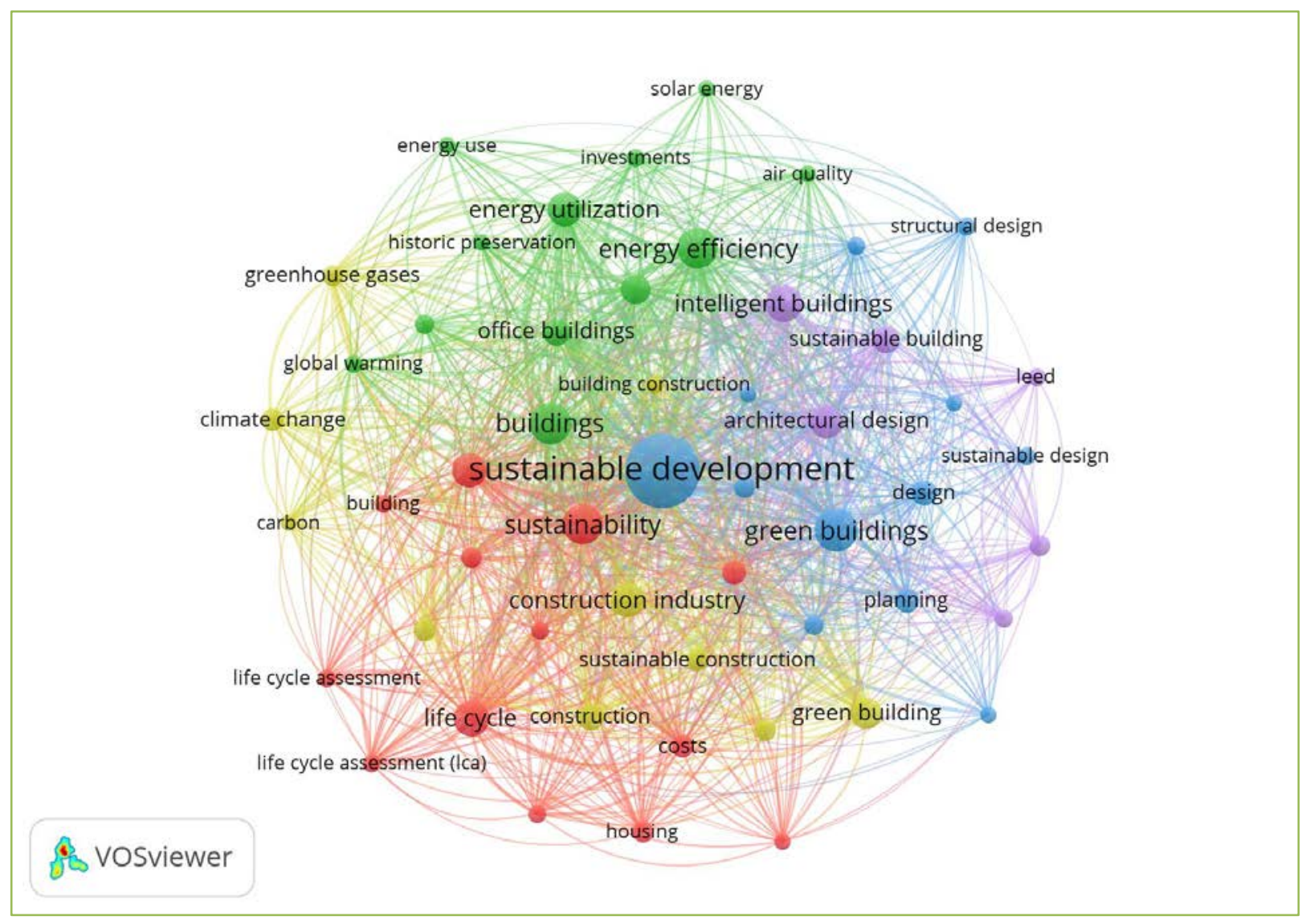

Figure 8. Keyword - Network Visualization 


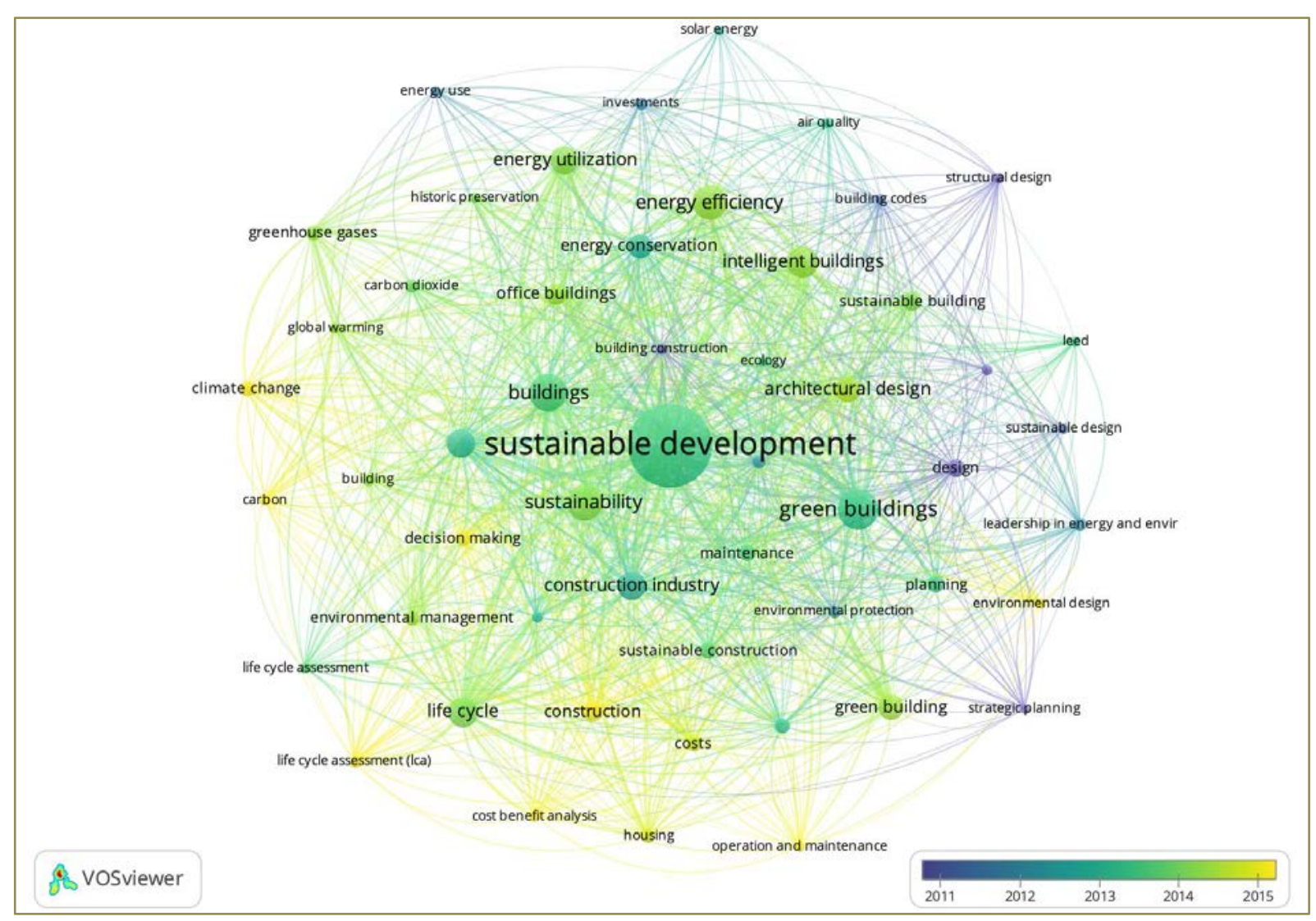

Figure 9. Keyword - Overlay Visualization

Figure 9 shows the development of keywords within the period of 1999 - 2019. In the Early Years (1999 2012), major research areas were around design, sustainable design, building construction, structural design, investment, strategic planning, environmental protection, and energy use. In the middle period (2012 - 2014), many studies on sustainable development, construction industry, energy efficiency, and planning were conducted. Meanwhile, in the last years $(2014$ - 2019), the research areas began to move towards life cycle assessment, climate change, carbon, housing, operation, and management.

In this study, the main areas of research are divided by 3 groups organized by the number of occurrences of the keywords (Table 5). The group consists of Group 1 which is a category of keywords classified as often used with Occurrence level $\geq 50$. Group 2 is a medium category with occurrence level of keywords 50> $x>25$. Group 3 covers keywords which falls into the category of rarely used, namely keywords with occurrences $26>x>19$.
Group 1 (frequent category) consists of 16 keywords, including sustainable development, green buildings, sustainability, energy efficiency, intelligent buildings, life cycle, industrial construction, environmental impact, energy utilization, architectural design, energy conservation, office buildings, construction, and sustainable building. Group 2 (medium category) comprises keywords that are commonly used in the literature, which include design, maintenance, planning, sustainable construction, climate change, costs, environmental management, building materials, housing, environmental protection, investments, and life cycle assessment. In Group 3 (rare category), the top 3 keywords include cost benefit analysis, global warming, building codes, building construction, environmental sustainability, sustainable design, environmental design, structural design, water quality, carbon, ecology, operation and maintenance, energy use, historic preservation, societies and institutions, solar energy, and strategic planning. 
Table 5. Keyword Grouping

\begin{tabular}{|c|c|c|c|c|c|c|c|c|c|c|c|}
\hline No & Keyword & $\begin{array}{c}\text { Occurrences } \\
(>50)\end{array}$ & $\begin{array}{c}\text { Total Link } \\
\text { Strength }\end{array}$ & No & Keyword & $\begin{array}{c}\text { Occurrences } \\
(50>X>25) \\
\end{array}$ & $\begin{array}{l}\text { Total Link } \\
\text { Strength }\end{array}$ & No & Keyword & $\begin{array}{c}\text { Occurrences } \\
(26>X>19) \\
\end{array}$ & $\begin{array}{c}\text { Total Link } \\
\text { Strength }\end{array}$ \\
\hline 1 & $\begin{array}{l}\text { sustainable } \\
\text { development }\end{array}$ & 396 & 1853 & 17 & design & 49 & 269 & 35 & cost benefit analysis & 25 & 175 \\
\hline 2 & green buildings & 140 & 805 & 18 & maintenance & 43 & 203 & 36 & global warming & 25 & 155 \\
\hline 3 & buildings & 126 & 784 & 19 & planning & 41 & 213 & 37 & building codes & 24 & 142 \\
\hline 4 & sustainability & 119 & 539 & 20 & $\begin{array}{c}\text { sustainable } \\
\text { construction }\end{array}$ & 40 & 207 & 38 & $\begin{array}{l}\text { building } \\
\text { construction }\end{array}$ & 24 & 144 \\
\hline 5 & energy efficiency & 115 & 683 & 21 & climate change & 37 & 180 & 39 & $\begin{array}{l}\text { environmental } \\
\text { sustainability }\end{array}$ & 24 & 126 \\
\hline 6 & intelligent buildings & 101 & 602 & 22 & costs & 37 & 257 & 40 & leed & 24 & 122 \\
\hline 7 & life cycle & 92 & 586 & 23 & $\begin{array}{c}\text { environmental } \\
\text { management }\end{array}$ & 37 & 205 & 41 & $\begin{array}{c}\text { life cycle } \\
\text { assessment }\end{array}$ & 24 & 147 \\
\hline 8 & $\begin{array}{l}\text { construction } \\
\text { industry }\end{array}$ & 90 & 564 & 24 & decision making & 35 & 234 & 42 & sustainable design & 24 & 77 \\
\hline 9 & $\begin{array}{l}\text { environmental } \\
\text { impact }\end{array}$ & 87 & 501 & 25 & greenhouse gases & 35 & 245 & 43 & $\begin{array}{l}\text { environmental } \\
\text { design }\end{array}$ & 23 & 142 \\
\hline 10 & energy utilization & 86 & 527 & 26 & $\begin{array}{c}\text { project } \\
\text { management }\end{array}$ & 35 & 217 & 44 & structural design & 23 & 113 \\
\hline 11 & architectural design & 78 & 495 & 27 & building materials & 33 & 193 & 45 & air quality & 22 & 117 \\
\hline 12 & green building & 74 & 380 & 28 & housing & 32 & 182 & 46 & carbon & 22 & 168 \\
\hline 13 & energy conservation & 68 & 379 & 29 & $\begin{array}{l}\text { leadership in energy } \\
\text { and environmental } \\
\text { designs }\end{array}$ & 32 & 190 & 47 & ecology & 22 & 96 \\
\hline 14 & office buildings & 56 & 295 & 30 & carbon dioxide & 30 & 181 & 48 & $\begin{array}{l}\text { operation and } \\
\text { maintenance }\end{array}$ & 22 & 124 \\
\hline 15 & construction & 54 & 381 & 31 & $\begin{array}{l}\text { environmental } \\
\text { protection }\end{array}$ & 27 & 137 & 49 & energy use & 21 & 86 \\
\hline \multirow[t]{4}{*}{16} & sustainable building & 52 & 343 & 32 & building & 26 & 135 & 50 & $\begin{array}{c}\text { historic } \\
\text { preservation }\end{array}$ & 21 & 125 \\
\hline & & & & 33 & investments & 26 & 143 & 51 & $\begin{array}{c}\text { societies and } \\
\text { institutions }\end{array}$ & 21 & 87 \\
\hline & & & & 34 & $\begin{array}{c}\text { life cycle } \\
\text { assessment (lca) }\end{array}$ & 26 & 200 & 52 & solar energy & 20 & 70 \\
\hline & & & & & & & & 53 & strategic planning & 20 & 96 \\
\hline
\end{tabular}



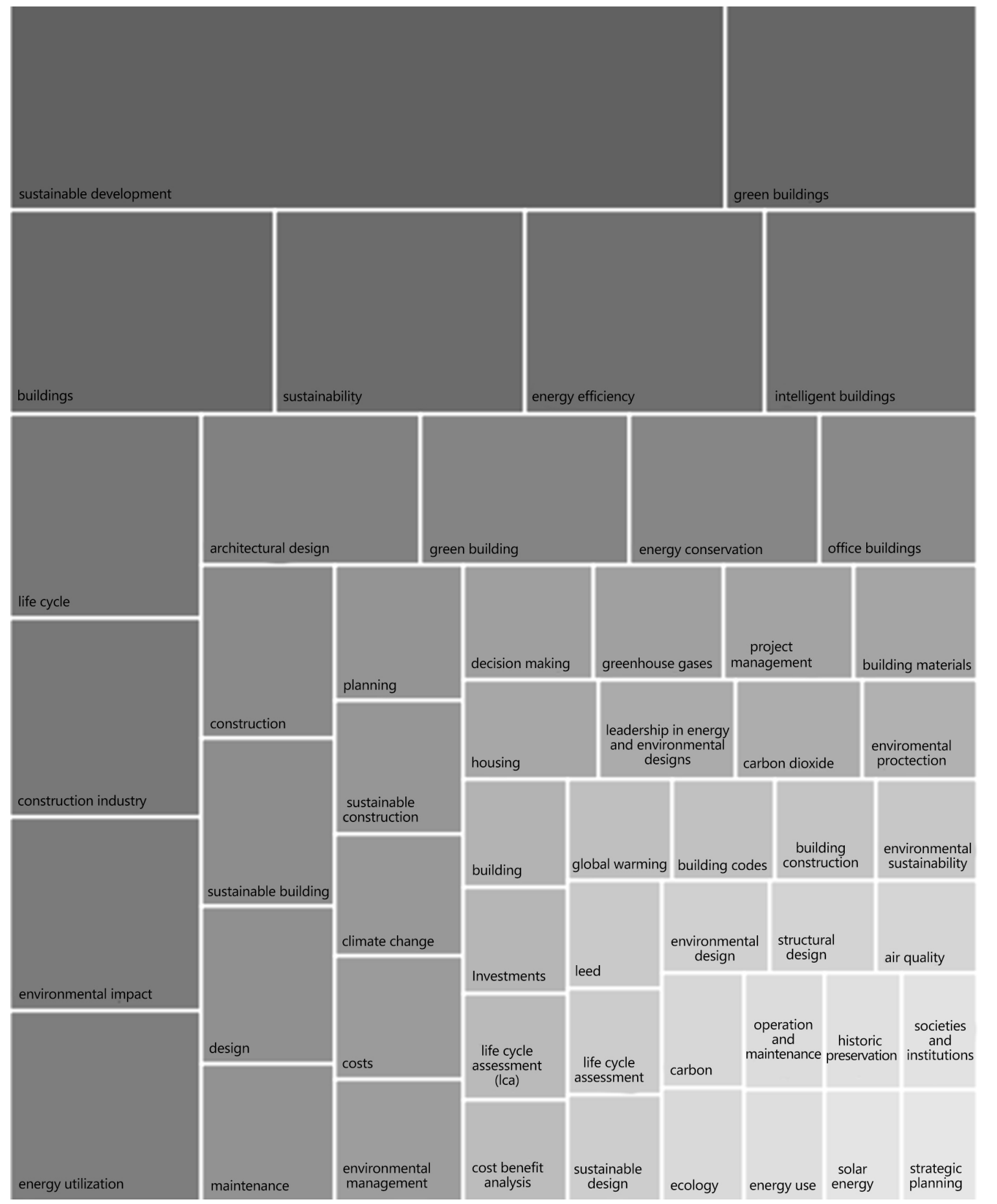

Figure 10. Treemap Main Research Area

Figure 10 displays the Treemap of main research areas. The main research areas that receive a sizeable and growing portion in discussing the operation and maintenance phases of sustainable green buildings include sustainable development, green buildings, buildings, sustainability, energy efficiency, and intelligent building. Meanwhile, research areas that are underdeveloped or get a small proportion in the period of observation include strategic planning, societies and institutions, operations and maintenance, energy use, and ecology.

Based on the division of the group and the Treemap, information on the categorization of keywords is the basis for the main research area, where the proportion of research keywords is seen based on the level of frequency of use (frequent, medium, rarely) by researchers in conducting their studies. This is one of the functions of 
this analysis where the combination of keyword categorization gives an opportunity to encourage the presence of new studies to complement existing studies, so that research in this field can continue to develop and the gaps can be seen and filled properly.

\section{Conclusions}

Management of operational phases and sustainable maintenance of green buildings can guarantee and improve the performance of green buildings as planned. From the results of science mapping, 746 publications are found in the period of 1999 - 2019. The types of publications that have a large contribution come from Articles (43.2\%), conference papers (43.0\%), and conference reviews (4.3\%) with the 3 most influential sources are the Journal of Green Building (25 documents), Advance Material Research (24 documents), Applied Mechanics and Materials (21 documents).

The mapping results reveal that 82 countries have contributed to research related to the operation phase and maintenance of sustainable green buildings. The United States (221 publications), China (84 publications), and Malaysia (52 publications) are 3 countries that have the largest and the most influential contributions in this field compared to other countries.

Based on the aspect of authors with the highest number of contributions, the 3 authors with the highest number of documents are Perini, K. (6 documents), Wang, Y. (6 documents), and Chew, M.Y.L. (5 documents). Meanwhile, based on the number of citations, the 3 authors with the highest number of citations are Zhang, X. (300 citations), Shen, L. (284 citations), and Wu, Y. (191 citations).

From 1999-2019, Sustainable construction-The role of environmental assessment tools (Ding, 2008), The moderating effects of institutional pressures on emergent green supply chain practices and performance (Zhu and Sarkis, 2007), and Balancing priorities: Decision-making in sustainable supply chain management (Wu and Pagell, 2011) are the 3 most cited publications and references in the world.

So far, the major areas of study have been dominated by research in the field of engineering (37.8\%), environmental science (17.6\%), energy (11.6\%), and social science (11.1\%). Meanwhile, other fields of study have contributions below $10 \%$, such as Business, Management and Accounting 7.2\%, Computer Science $5.3 \%$, Materials Science 4.3\%, Earth and Planetary Sciences 3.1\%, and Decision Sciences 2.1\%.

The main research area is identified through the keywords used. During the period of 1999 - 2012, the main research areas were design, sustainable design, building construction, structural design, investment, strategic planning, environmental protection, and energy use. During 2012-2014, the main research areas were related to sustainable development, construction industry, energy efficiency, and planning. Meanwhile, in the 2014-2019 period, the main study areas were life cycle assessments, climate change, carbon, housing, operations and management.

If the main research area is reviewed from keyword occurrences, the top 3 keywords found in Group 1 (frequent categories) consist of sustainable development, green buildings, and buildings in general, keywords in Group 2 (medium category) consist of design, maintenance, and planning, and keywords in Group 3 (rare category) consist of cost-benefit analysis, global warming, and building codes.

During the period 1999 - 2019, research area that is considered as experiencing significant development is the area that discusses sustainable development, green buildings, buildings, sustainability and energy efficiency and intelligent building. Meanwhile, the less developed research area is an area that examines strategic planning, societies and institutions, operation and maintenance, energy use, and ecology.

This study offers holistic knowledge development of papers that have relevance to the operation and maintenance phase of green buildings to ensure sustainable building performance. The results obtained are expected to increase knowledge and future researchers can identify and address the gap of the research area that is deemed to be done further studies to complete the existing research literature. This study has some limitations, although testing and analysis have been completed. Among them are the depth of discussions which is limited by space and the use of data sources that only use Scopus. This study does not map papers from other sources which are relevant to the topic discussed.

\section{REFERENCES}

[1] S. N. Kamaruzzaman, E. C. W. Lou, N. Zainon, N. S. Mohamed Zaid, and P. F. Wong, "Environmental assessment schemes for non-domestic building refurbishment in the Malaysian context," Ecol. Indic., vol. 69, pp. 548-558, Oct. 2016, doi: 10.1016/j.ecolind.2016.04. 031.

[2] IPCC, “Transport. In: Climate Change 2014: Mitigation of Climate Change. Contribution of Working Group III to the Fifth Assessment Report of the Intergovernmental Panel on Climate Change,” 2014.

[3] M. N. Uddin, A. M. Selvam, J. Shahoonda, and R. Prasanth, "Optimization of green building for low-income people at pondicherry,” Civ. Eng. Archit., vol. 6, no. 6, pp. 283-292, 2018, doi: 10.13189/cea.2018.060602.

[4] J. Zuo and Z. Y. Zhao, "Green building research-current status and future agenda: A review,” Renew. Sustain. Energy Rev., vol. 30, pp. 271-281, 2014, doi: 10.1016/j.rser.2013.1 
0.021 .

[5] P. Rocha and R. C. Rodrigues, "Bibliometric review of improvements in building maintenance,” J. Qual. Maint. Eng., vol. 23, no. 4, pp. 437-456, 2017, doi: 10.1108/JQME-07-2016-0030.

[6] S. Sadi-Nezhad, "A scientometrics study on green building: A DEA application,” J. Proj. Manag., pp. 189-194, 2019, doi: 10.5267/j.jpm.2019.4.001.

[7] M. Wang, P. Liu, Z. Gu, H. Cheng, and X. Li, “A scientometric review of resource recycling industry," Int. $J$. Environ. Res. Public Health, vol. 16, no. 23, Dec. 2019, doi: 10.3390/ijerph16234654.

[8] S. Ning and X. Li, "A scientometric review of emerging trends in green manufacturing," Adv. Intell. Syst. Comput., vol. 1001, pp. 234-247, 2019, doi: 10.1007/978-3-030-2124 8-3_17.

[9] J. Zuo, B. Xia, Q. Chen, S. Pullen, M. Skitmore, and A. Professor, "Green Building Rating for Office Buildings-Lessons Learned,” J. Green Build., vol. 11, no. 2, pp. 131-146, 2016.

[10] C. Meyer, "The greening of the concrete industry," Cem. Concr. Compos., vol. 31, no. 8, pp. 601-605, Sep. 2009, doi: 10.1016/j.cemconcomp.2008.12.010.

[11] H. Afshari, M. H. Issa, and Q. Peng, "Barriers to the design, construction, operation and maintenance of green building: A state-of-the-art review," Proceedings, Annu. Conf. - Can. Soc. Civ. Eng., vol. 1, no. May, 2013.

[12] M. F. Khamidi and O. A. Lateef, "BUILDING MAINTENANCE: A PATH TOWARDS SUSTAINABILI TY,” Malaysian Constr. Res. J., vol. 7, no. 2, pp. 47-59, 2010.

[13] C. Chen, Mapping scientific frontiers: The quest for knowledge visualization, Second., vol. 9781447151. Springer-Verlag London Ltd, 2013.

[14] M. J. Cobo, A. G. López-Herrera, E. Herrera-Viedma, and F. Herrera, "Science mapping software tools: Review, analysis, and cooperative study among tools," J. Am. Soc. Inf. Sci. Technol., vol. 62, no. 7, pp. 1382-1402, Jul. 2011, doi: 10.1002/asi.21525.

[15] M. P. R. Bolívar, L. A. Muñoz, and M. J. Cobo, “Analyzing the scientific evolution and impact of e-Participation research in JCR journals using science mapping," Int. J. Inf. Manage., vol. 40, pp. 111-119, Jun. 2018, doi: 10.1016/j.ijinfomgt.2017.12.011.

[16] N. J. van Eck and L. Waltman, VOSviwer Manual, no. October. Universiteit Leiden, 2017.

[17] B. C. Lippiatt, "Selecting Cost-Effective Green Building Products: BEES Approach,” J. Constr. Eng. Manag., no. November/December, pp. 1-4, 1999.

[18] B. N. Winther and A. G. Hestnes, "Solar Versus Green: The Analysis Of A Norwegian Row House,” Sol. Energy, vol. 66, no. 6, pp. 387-393, 1999, doi: DOI:10.1016/S0038-092X(9 9)00037-7.

[19] N. Kohler, "The relevance of Green Building Challenge: An observer's perspective,” Build. Res. Inf., vol. 27, no. 4-5, pp. 309-320, 1999, doi: 10.1080/096132199369426.
[20] S. Curwell, A. Yates, N. Howard, B. Bordass, and J. Doggart, "The Green Building Challenge in the UK," Build. Res. Inf., vol. 27, no. 4-5, pp. 286-293, 1999, doi: 10.1080/096132199369390.

[21] Q. Zhu and J. Sarkis, “The moderating effects of institutional pressures on emergent green supply chain practices and performance," Int. J. Prod. Res., vol. 45, no. 18-19, pp. 4333-4355, Sep. 2007, doi: 10.1080/00207540701440345.

[22] Z. Wu and M. Pagell, "Balancing priorities: Decision-making in sustainable supply chain management," J. Oper. Manag., vol. 29, no. 6, pp. 577-590, Sep. 2011, doi: 10.1016/j.jom.2010.10.001.

[23] X. Zhang, L. Shen, and Y. Wu, “Green strategy for gaining competitive advantage in housing development: A China study,” J. Clean. Prod., vol. 19, no. 2-3, pp. 157-167, Jan. 2011, doi: 10.1016/j.jclepro.2010.08.005.

[24] B. Li and R. Yao, "Urbanisation and its impact on building energy consumption and efficiency in China," Renew. Energy, vol. 34, no. 9, pp. 1994-1998, Sep. 2009, doi: 10.1016/j.renene.2009.02.015.

[25] A. Ghaffarianhoseini, N. D. Dahlan, U. Berardi, A. Ghaffarianhoseini, N. Makaremi, and M. Ghaffarianhoseini, "Sustainable energy performances of green buildings: A review of current theories, implementations and challenges," Renewable and Sustainable Energy Reviews, vol. 25. pp. 117, 2013, doi: 10.1016/j.rser.2013.01.010.

[26] K. Y. Foo, “A vision on the role of environmental higher education contributing to the sustainable development in Malaysia,” J. Clean. Prod., vol. 61, pp. 6-12, Dec. 2013, doi: 10.1016/j.jclepro.2013.05.014.

[27] A. M. Forster, K. Carter, P. F. G. Banfill, and B. Kayan, "Green maintenance for historic masonry buildings: an emerging concept,” Build. Res. Inf., vol. 39, no. 6, pp. 654664, 2011, doi: 10.1080/09613218.2011.621345.

[28] B. Nunes and D. Bennett, "Green operations initiatives in the automotive industry: An environmental reports analysis and benchmarking study,” Benchmarking, vol. 17, no. 3, pp. 396-420, 2010, doi: 10.1108/14635771011049362.

[29] G. K. C. Ding, "Sustainable construction-The role of environmental assessment tools," J. Environ. Manage., vol. 86, no. 3, pp. 451-464, Feb. 2008, doi:10.1016/j.jenvman.2 006.12 .025 .

[30] X. Zhang, L. Shen, V. W. Y. Tam, and W. W. Y. Lee, "Barriers to implement extensive green roof systems: A Hong Kong study,” Renew. Sustain. Energy Rev., vol. 16, no. 1, pp. 314-319, 2012, doi: 10.1016/j.rser.2011.07.157.

[31] J. Warnken, M. Bradley, and C. Guilding, "Eco-resorts vs. mainstream accommodation providers: An investigation of the viability of benchmarking environmental performance," Tour. Manag., vol. 26, no. 3, pp. 367-379, Jun. 2005, doi: 10.1016/j.tourman.2003.11.017.

[32] B. C. Lippiatt, "Selecting Cost-Effective Green Building Products: BEES Approach,” J. Constr. Eng. Manag., vol. 125, no. 6, pp. 448-455, 1999, doi: DOI: 10.1061/(ASCE)0733-9364(1999)125:6(448).

[33] R. M. Pulselli, E. Simoncini, F. M. Pulselli, and S. Bastianoni, "Emergy analysis of building manufacturing, 
maintenance and use: Em-building indices to evaluate housing sustainability,” Energy Build., vol. 39, no. 5, pp. 620-628, May 2007, doi: 10.1016/j.enbuild.2006.10.004.

[34] Y. Deng, Z. Li, and J. M. Quigley, "Economic returns to energy-efficient investments in the housing market: Evidence from Singapore,” Reg. Sci. Urban Econ., vol. 42, no. 3, pp. 506-515, May 2012, doi: 10.1016/j.regsciurbeco. 2011.04.004.

[35] C. J. C. Jabbour and A. B. L. De Sousa Jabbour, "Green Human Resource Management and Green Supply Chain Management: Linking two emerging agendas," J. Clean. Prod., vol. 112, pp. 1824-1833, Jan. 2016, doi: 10.1016/j.jclepro.2015.01.052.

[36] A. Dey, P. LaGuardia, and M. Srinivasan, "Building sustainability in logistics operations: A research agenda," Management Research Review, vol. 34, no. 11. pp. 12371259, Oct-2011, doi: 10.1108/01409171111178774.

[37] M. Ottelé, K. Perini, A. L. A. Fraaij, E. M. Haas, and R. Raiteri, "Comparative life cycle analysis for green façades and living wall systems,” Energy Build., vol. 43, no. 12, pp. 3419-3429, Dec. 2011, doi: 10.1016/j.enbuild.2011.09.010.

[38] J. H. Breuste, “Decision making, planning and design for the conservation of indigenous vegetation within urban development," in Landscape and Urban Planning, 2004, vol. 68, no. 4, pp. 439-452, doi: 10.1016/S0169-2046(03)00150 $-6$.

[39] J. K. W. Wong and J. Zhou, "Enhancing environmental sustainability over building life cycles through green BIM: A review,” Autom. Constr., vol. 57, pp. 156-165, Jun. 2015, doi: 10.1016/j.autcon.2015.06.003.
[40] D. Hou and A. Al-Tabbaa, "Sustainability: A new imperative in contaminated land remediation," Environ. Sci. Policy, vol. 39, pp. 25-34, 2014, doi: 10.1016/j.envsci.2014 .02 .003 .

[41] Y. Guo, M. Asce, and B. W. Baetz, "Sizing of Rainwater Storage Units for Green Building Applications,” doi: 10.1061/ASCE1084-0699200712:2197.

[42] C. J. Kibert, "The next generation of sustainable construction,” Building Research and Information, vol. 35, no. 6. pp. 595-601, Nov-2007, doi: 10.1080/096132107014 67040 .

[43] I. Y. Wuni, G. Q. P. Shen, and R. Osei-Kyei, "Scientometric review of global research trends on green buildings in construction journals from 1992 to 2018," Energy Build., vol. 190, pp. 69-85, May 2019, doi: 10.1016/j.enbuild.2019.02. 010.

[44] M. Oraee, M. R. Hosseini, E. Papadonikolaki, R. Palliyaguru, and M. Arashpour, "Collaboration in BIM-based construction networks: A bibliometric-qualitative literature review,” Int. J. Proj. Manag., vol. 35, no. 7, pp. 1288-1301, Oct. 2017, doi: 10.1016/j.ijproman.2017.07.001.

[45] R. Jin, S. Gao, A. Cheshmehzangi, and E. Aboagye-Nimo, "A holistic review of off-site construction literature published between 2008 and 2018,” J. Clean. Prod., vol. 202, pp. 1202-1219, Nov. 2018, doi: 10.1016/j.jclepro.2018.08. 195.

[46] M. R. Hosseini, I. Martek, E. K. Zavadskas, A. A. Aibinu, M. Arashpour, and N. Chileshe, "Critical evaluation of off-site construction research: A Scientometric analysis," Autom. Constr., vol. 87, pp. 235-247, Mar. 2018, doi: 10.1016/j.autcon.2017.12.002. 